\title{
LOCAL AIR AND SOIL TEMPERATURE MODELING USING HIMAWARI 8 SATELLITE IMAGERY
}

\author{
Adhia Azhar Fauzan ${ }^{1 *}$, Komariah ${ }^{2}$, Sumani ${ }^{2}$, Dwi Priyo Ariyanto ${ }^{2}$, and Tuban Wiyoso ${ }^{3}$ \\ ${ }^{1}$ Undergraduate Program of Soil Science Dept., Faculty of Agriculture, \\ Sebelas Maret University, Surakarta, Indonesia \\ ${ }^{2}$ Department of Soil Science, Faculty of Agriculture, Sebelas Maret University, \\ Surakarta, Indonesia, \\ ${ }^{3}$ Indonesian Agency for Meteorology, Climatology, and Geophysics, \\ Climatology Station of Semarang District, Indonesia \\ Submitted :2018-08-16 Accepted : 2018-12-03
}

\begin{abstract}
Himawari 8 satellite image, which was launched in October 2014 and began the operational in July 2015 , serves to identify and track the phenomenon of rapid changes in weather. The purpose of this research was to determine the model of local air and soil temperatures using Himawari-8 satellite image. Local air and soil temperatures information were collected from the Climatology Station of Semarang district, Central Java, Indonesia. Interpretation of the Himawari-8 satellite image was performed, as well as the statistical tests of correlation and regression, according to the sun's pseudo motion. Pair correlation and regression analysis on satellite image with air temperature; and air temperature with soil temperature (bare and grass). The results showed the satellite imagery of Himawari-8 could predict the air and soil temperatures, especially bare soil. In specific, the accuracies were higher on soil temperature at 0 (surface) and $5 \mathrm{~cm}$ depth. But each period produced vary accuracy, due to many weather elements had may affect the air and soil temperatures.
\end{abstract}

Keywords: Bare soil, grass soil, Climatology Station of Semarang District

How to Cite: Fauzan, A.A., Komariah, Sumani, Ariyanto, D.P., and Wiyoso, T. (2018). Local Air and Soil Temperature Modeling Using Himawari 8 Satellite Imagery. Sains Tanah Journal of Soil Science and Agroclimatology, 15(2): 123-133 (doi: 10.15608/stjssa.v15i2.23020)

Permalink/DOI: http://dx.doi.org/10.15608/stjssa.v15i2.23020

\section{INTRODUCTION}

The soil temperature is less used as an indicator of land feasibility for crop cultivation. Soil temperatures support plant productivity

\footnotetext{
* Corresponding Author :

Email: adhia.aaf@gmail.com
}

processes (Jungqvist et al., 2014). However, observation of soil temperature requires more as it affects the hydrological and biogeochemical equipment and observers, so it is less practical. The regional soil temperature measurement can be estimated from standard meteorological data (Kätterer \& 
Andrén, 2009). Employing the satellite imagery to facilitate observation / predicting soil temperature, is an approach.

Himawari 8 is the latest generation of Japan Meteorological Agency (JMA), a meteorological geostationary satellite that carries the latest optical sensors with radiometric, spectral, and spatial resolution much higher than those previously in geostationary orbit. Launched from Japan's Tanegashima Space Center using H-IIA rocket on 7 October 2014, the new Himawari 8 was in its geostationary orbit on 16 October 2014, and starting operations from 7 July 2015 to 2022. Position in geostationary orbit $140.7^{\circ} \mathrm{E}$; $35,800 \mathrm{~km}$ in over the equator, and become part of The Space-based Global Observing System (GOS) program of the World Meteorological Organization (WMO). Himawari 8 provides water and cloud images to more than 30 countries and regions, contributes to weather forecasts and natural disaster relief, and supports safer transportation in the East Asia and Pacific region (Bessho et al., 2016).

Geostationary meteorological satellites are recognized and proven to be useful in monitoring and predicting weather such as tornadoes, tropical cyclones and flash floods in the short run as well as climatic trends indicated by long-term sea temperatures, biomass burning, cloud cover and long-range rays (Menzel, Tobin, \& Revercomb, 2016). Indonesian Meteorology, Climatology and Geophysics Agency (BMKG) cooperated with the Japan Meteorological Agency (JMA) of utilizing Himawari satellite image to support BMKG for meteorological purposes. However,
BMKG has not utilized Himawari satellite imagery for climatological purposes. According to (Forsythe et al., 2015) clouds play an important role in the hydro-climatological variability by altering the balance of surface energy, air temperature, and soil temperature.

From a regional-scale agricultural perspective, it is important to know the approximate the air and soil temperatures to estimate the water balance and evapotranspiration, but many weather stations do not provide such data (Flores P \& Lillo S, 2010). Climate change today can already be identified using technological assistance, research related to climate component changes is growing. One way to monitor the condition of air and soil temperatures is by using remote sensing technology. Therefore, the air and soil temperatures monitoring can be carried out easier and practically, without always plunging into the field or waiting, the data can be obtained and updated. Until now no research has been done regarding the analysis of satellite images of Himawari for air and soil temperatures modeling, so no information has been found. As the remote sensing technology on weather continues to grow, it is necessary to analyze the Himawari satellite imagery for monitoring air and soil temperatures. It is expected that this monitoring can minimize losses in agriculture caused by temperature fluctuations. Therefore, the purpose of this research was to determine the model of local air and soil temperatures using Himawari-8 satellite image. 


\section{MATERIALS AND METHOD}

\section{Data}

The data of satellite images of Himawari 8 are obtained from the climatology station of Semarang district $\left(6^{\circ} 59^{\prime} 05.87^{\prime \prime} \mathrm{S}\right.$ and $\left.110^{\circ} 22^{\prime} 51.47^{\prime \prime} \mathrm{E}\right)$, Indonesia. The image obtained was hourly data, using band 13 with wavelength $10.4 \mu \mathrm{m}$ and spatial resolution 2 $\mathrm{km}$. The band 13-15 are the band specifically to observe the atmospheric conditions (Bessho et al., 2016). Since not all the Himawari 8 satellite image data were available, an interpolation was carried out to predict the missing data. Interpolation was conducted when maximum 3 data were missed. The data then were converted into local Indonesian time $(G M T+7)$. The satellite images of MTSAT-2 employed were from 1 January at 1 am until 6 July 12 am, 2015. The Himawari 8 satellite images used were from 7 July 2015 at 1 am until 30 September 2016 at 11 pm.

Air and soil temperatures data were obtained from the Climatology Station of Semarang district. The available air temperature data were 2-hourly-interval, from 2 am until 12 pm every day. On the other hand, the soil temperature data were only available at $7 \mathrm{am}, 1 \mathrm{pm}$, and $5 \mathrm{pm}$. Therefore, the interpolation between air and soil temperatures data was conducted to meet the time series. The air temperature data used were from 1 January 2015 to 30 September 2016. Meanwhile, the soil temperature data available were from bare and grass soil each at the depth of $0,5,10$, and $20 \mathrm{~cm}$.

\section{Data Analysis}

Regression analysis was employed to determine the pattern of each parameter, while Pearson's correlation analysis was conducted to find the correlation between each parameter. To simplify the correlation analysis, the data were divided into 4 groups according to the sun's pseudo motion (Patkó, Szeder, \& Patkó, 2013), i.e.: December-January-February (DJF), March-April-May (MAM), June-July-August (JJA), and September-October-November (SON).

Interpretation of Himawari 8 satellite images on pixels was classified into 15 temperature interval scales of air temperature (scale 1-15), according to the Himawari 8's standard estimation on air temperature (Bessho et al., 2016). The correlation analysis was carried out between Himawari image with air temperature, air temperature with soil temperature, and Himawari image with soil temperature. The regression analysis was also conducted on those with significantly correlated parameters.

\section{RESULTS}

\section{Interpretation of Himawari $\mathbf{8}$ Image}

Figure 1 shows the Himawari 8 image classification scale for 21 months. There were 15,336 total images, but only 13,426 images (87.55\%) were available, whereas 1,910 images (12.45\%) were not available. 654 of the missing data (4.26\%) were interpolated, but mostly data of April, May, and June 2015 were missed out and cannot be interpolated.

\section{Ambient air temperature}

The ambient air temperature data, which were recorded every 2 hours is presented in Figure 2. The highest ambient air temperature reached $40^{\circ} \mathrm{C}$ at $4 \mathrm{pm}$ on 2 
August 2015, while the lowest was $18^{\circ} \mathrm{C}$ at 0 am on 3 August in the same year. It can be seen in Figure 2 that the air temperature started to increase from April to October, then decreased in November. The air temperatures in 2016 were rather lower than those in 2015.

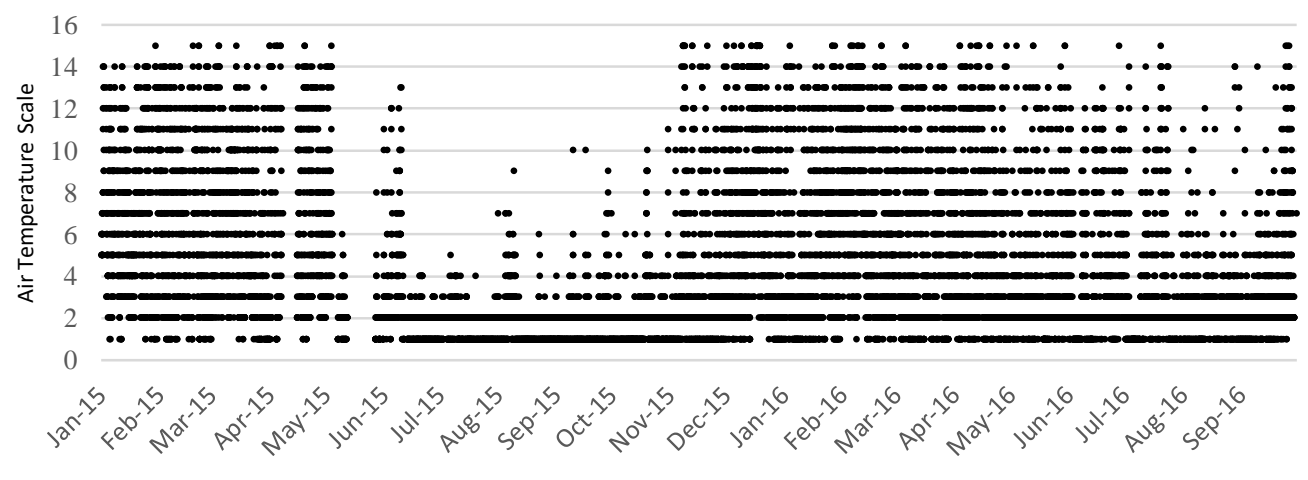

Day of the Year (DOY)

Figure 1. Air temperature scale classification of Himawari 8 images

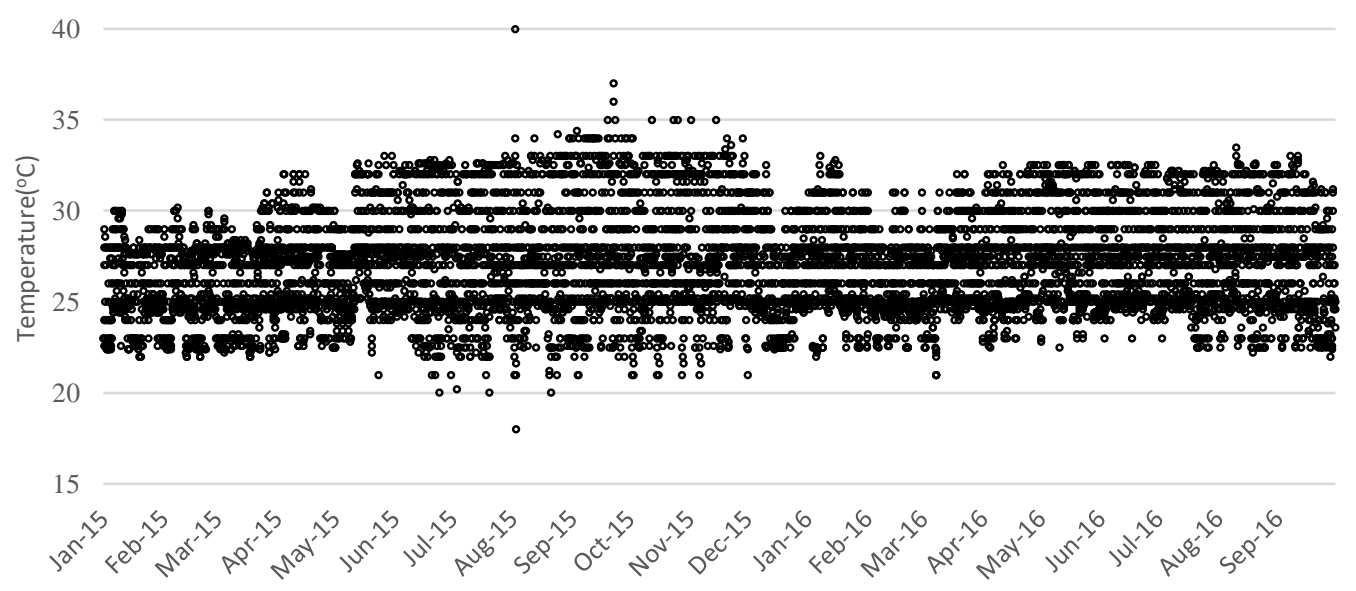

Figure 2. Ambient air temperature of 2-hourly recorded data (taken from Climatology Station of Semarang Regency, Indonesia)

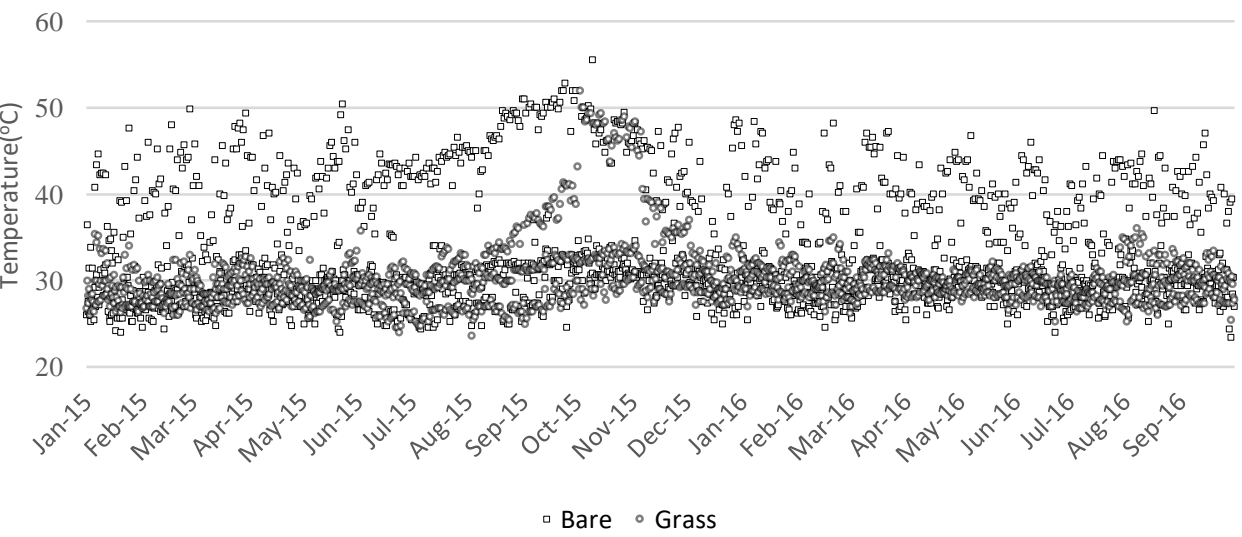

Figure 3. Soil temperatures (bare and grass) at $0 \mathrm{~cm}$ (taken from Climatology Station of Semarang Regency) 


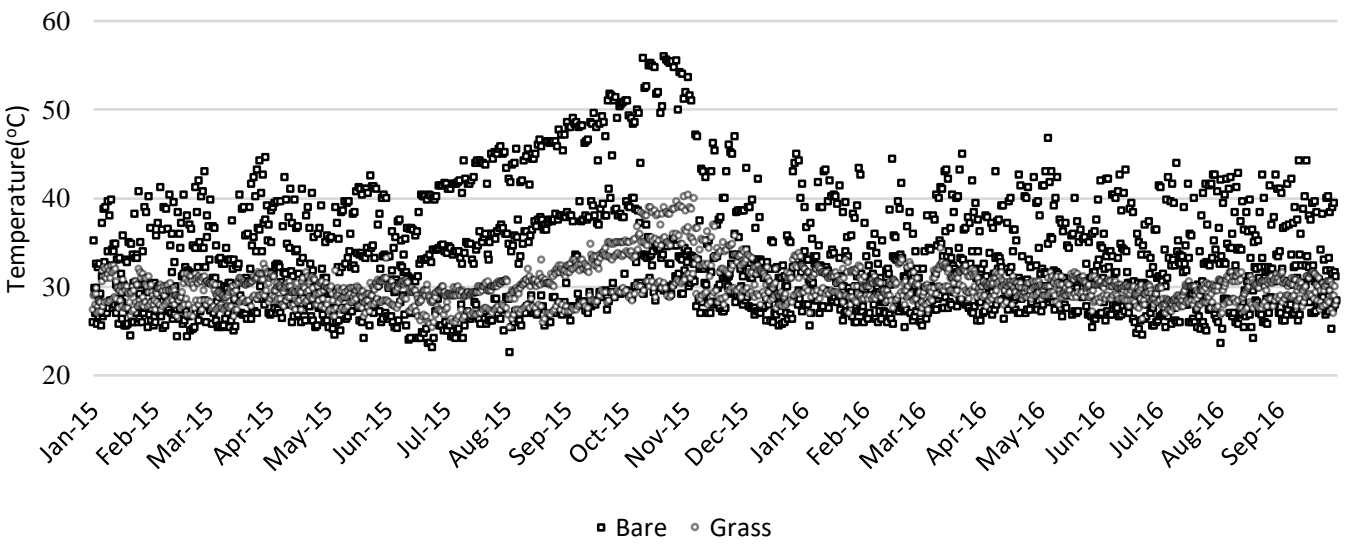

Figure 4. Soil temperature (bare and grass) at $5 \mathrm{~cm}$ (data were taken from Climatology Station of Semarang Regency)

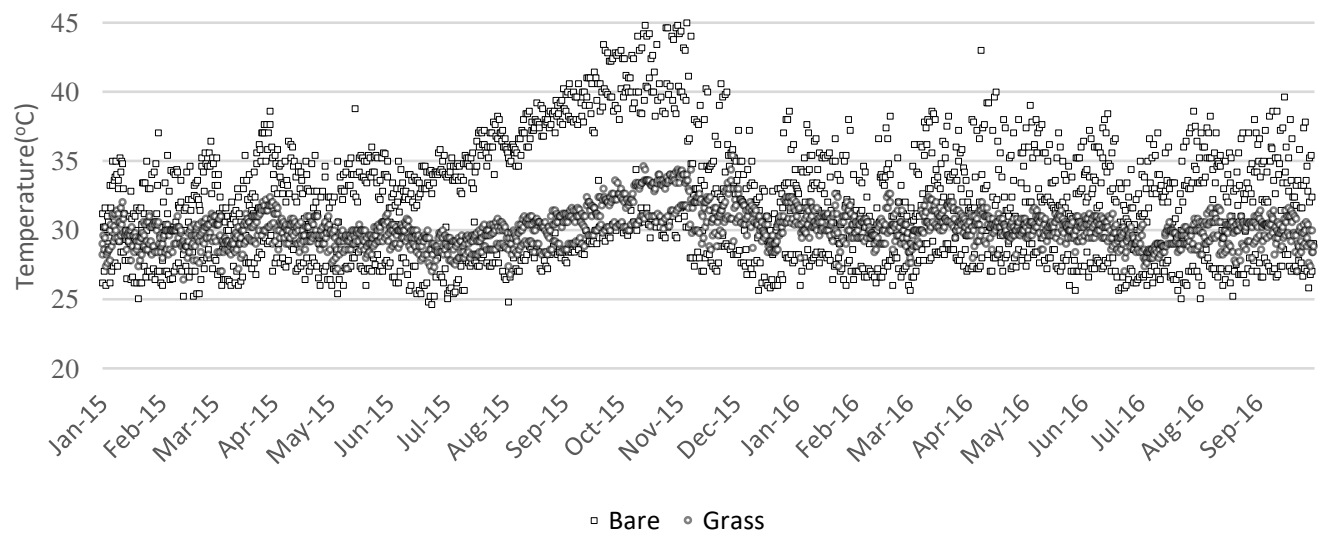

Figure 5. Soil temperatures of bare and grass at $10 \mathrm{~cm}$ (data taken from Climatology Station of Semarang Regency)

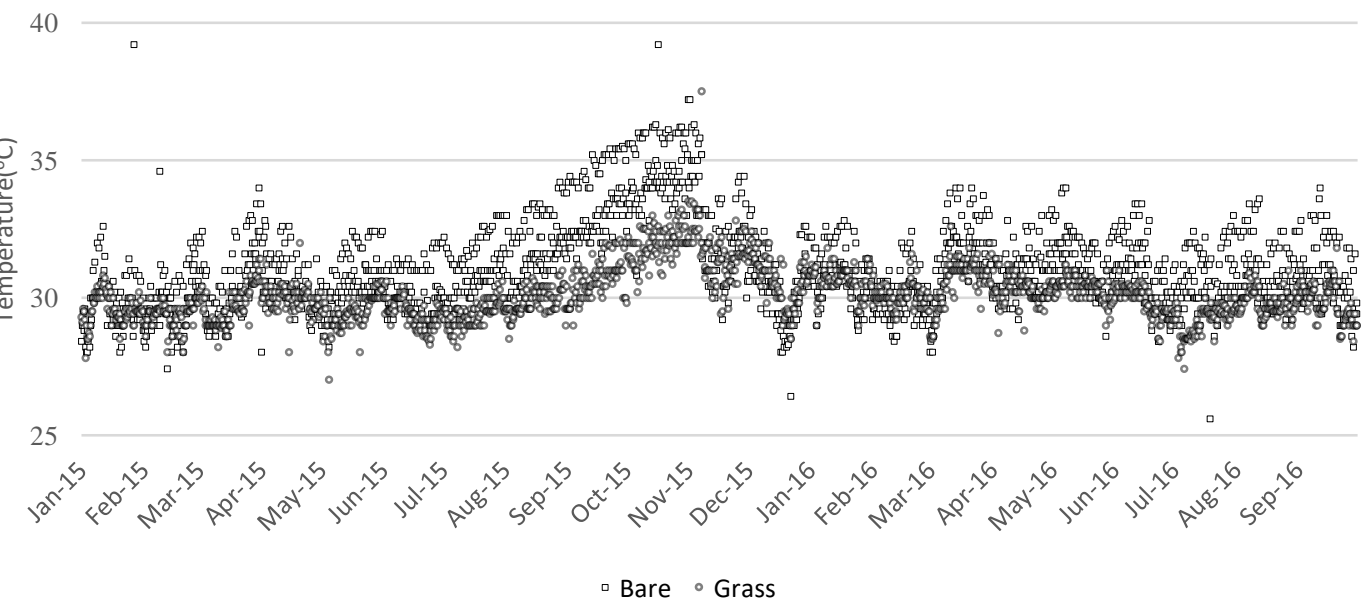

Figure 6. Soil temperature (bare and grass) at $20 \mathrm{~cm}$ depth (taken from Climatology Station of Semarang Regency, Indonesia) 
Fauzan et al. / SAINS TANAH - Journal of Soil Science and Agroclimatology, 15(2), 2018, 128

Table 1. Model of Satellite Himawari 8 image and air temperature

\begin{tabular}{ccc}
\hline Period & $\mathbf{R}^{2}$ & Model \\
\hline 2015 & & \\
JF & 0.1232 & $y=-1.104 \ln (x)+27.372$ \\
MAM & 0.0829 & $y=-0.866 \ln (x)+27.305$ \\
JJA & 0.1688 & $y=-2.547 \ln (x)+28.301$ \\
SON & 0.1477 & $y=-1.914 \ln (x)+28.711$ \\
\hline 2016 & & \\
DJF & 0.1487 & $y=-1.185 \ln (x)+28.127$ \\
MAM & 0.0886 & $y=-0.946 \ln (x)+28.194$ \\
JJA & 0.1062 & $y=-1.241 \ln (x)+28.366$ \\
\hline Overall & 0.1472 & $y=-1.269 \ln (x)+28.172$ \\
\hline
\end{tabular}

\section{Soil temperature}

Figure 3 shows the soil temperature at 0 $\mathrm{cm}$ (surface). The bare and grass soil reached the highest temperatures at $1 \mathrm{pm}$ on 9 October $\left(55.5^{\circ} \mathrm{C}\right)$ and $1 \mathrm{pm}$ on 2 October $\left(52^{\circ} \mathrm{C}\right)$ 2015, respectively. Meanwhile, the lowest was recorded at 7 am on 29 September $\left(23.4^{\circ} \mathrm{C}\right)$ and 7 am on 3 August $\left(23.6^{\circ} \mathrm{C}\right) 2016$, respectively.

Figure 4 presents the soil temperature at $5 \mathrm{~cm}$ depth of bare and grass soil. The highest temperature was $56^{\circ} \mathrm{C}$ (on 21 October 2015, at $1 \mathrm{pm}$ ) and $40.4^{\circ} \mathrm{C}$ (on 2 November 2015, at $1 \mathrm{pm}$ ) under the bare and grass soil, respectively. In the meantime, the lowest was $22.6^{\circ} \mathrm{C}$ (on 3 August $2015,7 \mathrm{am}$ ) and $25.4^{\circ} \mathrm{C}$ (on 24 June and 3 August 2017, at 7 am), respectively.

Figure 5 shows the soil temperature at $10 \mathrm{~cm}$ depth of each bare and grass soil. The highest and the lowest soil temperatures at bare soil were $46.6^{\circ} \mathrm{C}$ (on 21 October 2015 and 17 March 2016, at $1 \mathrm{pm}$ ) and $24.6^{\circ} \mathrm{C}$ (on 24 June 2015 , at 7 am), respectively. On the other hand, it was recorded that the highest and the lowest soil temperatures under grass soil were $35.4^{\circ} \mathrm{C}$ (on 29 November 2015 , at 1
Table 2. Pearson's Correlation between Himawari 8 images with ambient air temperature

\begin{tabular}{cccl}
\hline Period & Coeff. & Sig. & \multicolumn{1}{c}{$\mathbf{n}$} \\
\hline $\mathbf{2 0 1 5}$ & & & \\
JF & $-.227^{* *}$ & .000 & 708 \\
MAM & $-.230^{* *}$ & .000 & 1104 \\
JJA & $-.212^{* *}$ & .000 & 1104 \\
SON & $-.226^{* *}$ & .000 & 1092 \\
\hline $\mathbf{2 0 1 6}$ & & & \\
DJF & $-.303^{* *}$ & .000 & 1092 \\
MAM & $-.175^{* *}$ & .000 & 1104 \\
JJA & $-.185^{* *}$ & .000 & 1104 \\
Overall & $-.257^{* *}$ & .000 & 7668 \\
\hline
\end{tabular}

pm) and $26.4^{\circ} \mathrm{C}$ (on 13 February 2015 , at 7 am), respectively.

The soil temperatures of bare and grass soil at $20 \mathrm{~cm}$ depth is shown in Figure 6 . It can be seen $39.2^{\circ} \mathrm{C}$ (on 27 January 2015 at $1 \mathrm{pm}$ and 17 October 2015 at $4 \mathrm{pm}$ ) and $37.5^{\circ} \mathrm{C}$ (on 7 November 2015, at 5 pm) where the highest temperature under bare and grass soil, respectively. Meanwhile, the lowest was $25.6^{\circ} \mathrm{C}$ on (on 19 July 2016 at $7 \mathrm{am}$ ) and $27^{\circ} \mathrm{C}$ (on 5 May 2015 at 7 am), respectively.

In general, Fig. 3 to 6 shows that bare soil temperatures at all depths $(0,5,10$, and $20 \mathrm{~cm}$ ) started to increase from July to October and declined in November. Grass soil temperatures started to increase from August to November and declined in December. The pattern of soil temperatures fluctuation at bare and grass soil was relatively similar, but only the distribution was different. The bare soil temperature was more vary than that of grass soil.

\section{DISCUSSION}

\section{Air temperature modeling using Himawari 8} satellite images

Air temperature modeling using Himawari 8 satellite images was formulated using regression analysis (Table 1 ) if the 
correlations between air temperature and Satellite Himawari 8 images were significant (Table 2). It is shown in Table 2 that the Himawari 8 satellite images per sun motion pseudo-period very significantly correlated (Sig. < 0.01) with air temperatures at all periods. The correlations were negative with the coefficient $(r)$ ranged from -0.303 to -0.175 . Since the correlation was very significant, hence the following model can be employed to predict air temperature using satellite Himawari 8 images after the regression analysis (Table 1).

$$
y=-1.269 \ln (x)+28.172
$$

note: $y=$ air temperature

$\mathrm{x}=$ class of Himawari 8 imagery

Himawari 8 satellite imagery can be used to estimate the air temperature. This result is line with (Sadeghi et al., 2017), which states that since remote sensing provides excellent results for large-scale characteristics and monitoring of soil near the surface (0-5 $\mathrm{cm})$. Because soil optical reflection, thermal emissions, and microwave losses are highly correlated with soil observations. According to (Rahaman \& Hassan, 2017), remote sensing can be used to determine air temperature and is useful when applied to understand local heating trends if station-based weather data (annual average temperature and air temperature) is available. However, according to (Forsythe et al., 2015), clouds play an important role in the hydro-climatological variability by altering the balance of surface energy and air temperature, hence the coefficient of determination $\left(R^{2}\right)$ of the models are small. The correlation between local observations of near-surface temperatures and cloud cover fractions with satellite imagery strengthens the linkage between local atmospheric conditions and climate variability (air temperature) near the surface.

\section{Modeling of Himawari 8 Satellite Image and Soil Temperature}

The modeling equations to predict bare soil temperature at each depth $(0,5,10$, and $20 \mathrm{~cm}$ ) using the Himawari 8 satellite images are presented in Table 3. It can be seen in Table 3 that the model equation of 0 and $\mathrm{cm}$ depth was well produced at all seasons, but not at 10 and $20 \mathrm{~cm}$ depths. That is because nearly half of the root biomass was founded at a soil depth of less than $20 \mathrm{~cm}$ (Fan et al., 2016), after a depth of $30 \mathrm{~cm}$ the soil temperature fluctuation is smaller (Geiger, 1959). The regression analysis could not produce a model equation for 10 and $20 \mathrm{~cm}$ of bare soil temperatures at some seasons because Himawari 8 satellite images did not correlate (Sig. > 0.05) with soil temperatures at those specific depths and seasons (Table 4).

In the meantime, the modeling equations for Himawari 8 satellite images and grass soil temperatures at $0,5,10$, and $20 \mathrm{~cm}$ depths are displayed as Table 5 . Table 5 shows that in general, predicting soil temperatures with grass covers is difficult by using the Himawari 8 satellite images, due to only surface $(0 \mathrm{~cm})$ soil temperatures at specific seasons produced equation from the regression analysis. This is proven by the dominant insignificant correlations between Himawari 8 satellite images and grass soil temperatures (Table 6). 
Fauzan et al. / SAINS TANAH - Journal of Soil Science and Agroclimatology, 15(2), 2018, 130

Table 3. Modeling bare soil temperature with Himawari 8 satellite imagery

\begin{tabular}{|c|c|c|c|c|}
\hline Period & $0 \mathrm{~cm}$ & $5 \mathrm{~cm}$ & $10 \mathrm{~cm}$ & $20 \mathrm{~cm}$ \\
\hline \multicolumn{5}{|l|}{2015} \\
\hline JF & $y=-3.342 \ln (x)+36.557$ & $y=-1.79 \ln (x)+33.976$ & & \\
\hline MAM & $y=-2.999 \ln (x)+36.465$ & $y=-1.992 \ln (x)+34.54$ & $y=-0.87 \ln (x)+32.196$ & $y=-0.266 \ln (x)+30.726$ \\
\hline JJA & $y=-6.11 \ln (x)+35.971$ & $y=-6.734 \ln (x)+36.525$ & $y=-4.135 \ln (x)+33.942$ & $y=-0.795 \ln (x)+31.281$ \\
\hline SON & $y=-2.856 \ln (x)+36.808$ & $y=-3.203 \ln (x)+38.554$ & $y=-1.85 \ln (x)+36.55$ & \\
\hline \multicolumn{5}{|l|}{2016} \\
\hline DJF & $y=-3 \ln (x)+36.482$ & $y=-1.817 \ln (x)+34.333$ & $y=-0.937 \ln (x)+32.253$ & \\
\hline MAM & $y=-2.986 \ln (x)+36.216$ & $y=-1.825 \ln (x)+34.521$ & & $y=0.1738 \ln (x)+31.069$ \\
\hline JJA & $y=-2.747 \ln (x)+34.606$ & $y=-2.234 \ln (x)+33.851$ & $y=-1.268 \ln (x)+32.2$ & \\
\hline Overall & $y=-2.944 \ln (x)+35.856$ & $y=-2.777 \ln (x)+35.755$ & $y=-1.775 \ln (x)+33.83$ & $y=-0.585 \ln (x)+31.679$ \\
\hline
\end{tabular}

Note: Grey cell means no significant correlation hence regression analysis was not conducted

Table 4. Pearson's Correlation between Himawari 8 satellite images and bare soil temperatures at $0,5,10$, and $20 \mathrm{~cm}$ depths

\begin{tabular}{ccccccccccc}
\hline \multirow{2}{*}{ Period } & \multicolumn{2}{c}{$\mathbf{0} \mathbf{c m}$} & \multicolumn{2}{c}{$\mathbf{5} \mathbf{c m}$} & \multicolumn{2}{c}{$\mathbf{1 0} \mathbf{c m}$} & \multicolumn{2}{c}{$\mathbf{2 0} \mathbf{c m}$} & \multirow{2}{*}{$\mathbf{n}$} \\
\cline { 2 - 8 } & $\mathbf{r}$ & $\mathbf{S i g}$ & $\mathbf{r}$ & $\mathbf{S i g}$ & $\mathbf{r}$ & $\mathbf{S i g}$ & $\mathbf{r}$ & $\mathbf{S i g}$ & \\
\hline $\mathbf{2 0 1 5}$ & & & & & & & & & \\
JF & $-.282^{* *}$ & .000 & $-.159^{*}$ & .034 & -.028 & .713 & .021 & .785 & 177 \\
MAM & $-.206^{* *}$ & .001 & $-.181^{* *}$ & .003 & $-.133^{*}$ & .028 & $-.185^{* *}$ & .002 & 276 \\
JJA & $-.224^{* *}$ & .000 & $-.274^{* *}$ & .000 & $-.259^{* *}$ & .000 & $-.177^{* *}$ & .003 & 276 \\
SON & $-.174^{* *}$ & .004 & $-.177^{* *}$ & .003 & $-.163^{* *}$ & .007 & -.065 & .286 & 273 \\
$\mathbf{2 0 1 6}$ & & & & & & & & & \\
DJF & $-.352^{* *}$ & .000 & $-.225^{* *}$ & .000 & $-.128^{* *}$ & .034 & .002 & .987 & 273 \\
MAM & $-.334^{* *}$ & .000 & $-.200^{* *}$ & .001 & -.106 & .077 & $.172^{* *}$ & .004 & 276 \\
JJA & $-.276^{* *}$ & .000 & $-.211^{* *}$ & .000 & $-.141^{*}$ & .019 & .013 & .824 & 276 \\
Overall & $-.280^{* *}$ & .000 & $-.246^{* *}$ & .000 & $-.206^{* *}$ & .000 & $-.167^{* *}$ & .000 & 1917 \\
\hline
\end{tabular}

Note: Grey cell means no significant correlation

Table 5. Modeling grass soil temperatures with Himawari 8 satellite imagery

\begin{tabular}{|c|c|c|c|c|}
\hline Period & $0 \mathrm{~cm}$ & $5 \mathrm{~cm}$ & $10 \mathrm{~cm}$ & $20 \mathrm{~cm}$ \\
\hline \multicolumn{5}{|l|}{2015} \\
\hline JF & $y=-0.736 \ln (x)+29.846$ & & & \\
\hline \multicolumn{5}{|l|}{ MAM } \\
\hline JJA & $y=-1.872 \ln (x)+29.846$ & $y=-0.905 \ln (x)+29.321$ & & \\
\hline SON & $y=-1.868 \ln (x)+34.723$ & & & $y=0.322 \ln (x)+31.298$ \\
\hline \multicolumn{5}{|l|}{2016} \\
\hline DJF & $y=-0.52 \ln (x)+30.875$ & & & \\
\hline MAM & & & $y=0.0773 \ln (x)+30.199$ & \\
\hline \multicolumn{5}{|l|}{ JJA } \\
\hline Overall & $y=-1.049 \ln (x)+31.139$ & & & \\
\hline
\end{tabular}

Note: Grey cell means no significant correlation hence regression analysis was not conducted 
Fauzan et al. / SAINS TANAH - Journal of Soil Science and Agroclimatology, 15(2), 2018, 131

Table 6. Correlation of Himawari 8 satellite imagery and grass soil temperature

\begin{tabular}{|c|c|c|c|c|c|c|c|c|c|}
\hline \multirow{2}{*}{ Period } & \multicolumn{2}{|c|}{$0 \mathrm{~cm}$} & \multicolumn{2}{|c|}{$5 \mathrm{~cm}$} & \multicolumn{2}{|c|}{$10 \mathrm{~cm}$} & \multicolumn{2}{|c|}{$20 \mathrm{~cm}$} & \multirow{2}{*}{$\mathbf{N}$} \\
\hline & $\mathbf{P}$ & Sig & $\mathbf{P}$ & Sig & $\mathbf{P}$ & Sig & $\mathbf{P}$ & Sig & \\
\hline \multicolumn{10}{|l|}{2015} \\
\hline JF & $-.162^{* *}$ & .031 & -.047 & .531 & -.014 & .853 & .036 & .637 & 177 \\
\hline MAM & -.028 & .643 & .084 & .162 & .050 & .411 & .043 & .476 & 276 \\
\hline JJA & $-.175^{* *}$ & .004 & $-.120^{*}$ & .047 & -.071 & .239 & .030 & .616 & 276 \\
\hline SON & $-.134^{*}$ & .026 & -.066 & .274 & .020 & .741 & $.222^{* *}$ & .000 & 273 \\
\hline \multicolumn{10}{|l|}{2016} \\
\hline DJF & $-.146^{*}$ & .016 & -.081 & .181 & -.036 & .554 & -.032 & .600 & 273 \\
\hline MAM & -.003 & .954 & .118 & .050 & $.145^{*}$ & .016 & .074 & .223 & 276 \\
\hline JJA & -.095 & .116 & .014 & .822 & .029 & .635 & .029 & .626 & 276 \\
\hline Overall & $-.130^{* *}$ & .000 & -.042 & .068 & .006 & .797 & .017 & .454 & 1917 \\
\hline
\end{tabular}

Note: Grey cell means no significant correlation

Table 7. The Coefficient of Determination $\left(R^{2}\right)$ of Himawari 8 satellite images and soil temperatures equation models at bare and grass soil at each depth

\begin{tabular}{|c|c|c|c|c|c|c|c|c|}
\hline \multirow{2}{*}{ Period } & \multicolumn{4}{|c|}{ Bare soil } & \multicolumn{4}{|c|}{ Grass soil } \\
\hline & $0 \mathrm{~cm}$ & $5 \mathrm{~cm}$ & $10 \mathrm{~cm}$ & $20 \mathrm{~cm}$ & $0 \mathrm{~cm}$ & $5 \mathrm{~cm}$ & $10 \mathrm{~cm}$ & $20 \mathrm{~cm}$ \\
\hline \multicolumn{9}{|l|}{2015} \\
\hline JF & 0.149 & 0.073 & & & 0.075 & & & \\
\hline MAM & 0.134 & 0.096 & 0.042 & 0.033 & & & & \\
\hline JJA & 0.152 & 0.226 & 0.215 & 0.110 & 0.123 & 0.079 & & \\
\hline SON & 0.047 & 0.051 & 0.041 & & 0.032 & & & 0.039 \\
\hline \multicolumn{9}{|l|}{2016} \\
\hline DJF & 0.191 & 0.102 & 0.055 & & 0.053 & & & \\
\hline MAM & 0.191 & 0.093 & & 0.016 & & & 0.005 & \\
\hline JJA & 0.131 & 0.097 & 0.063 & & & & & \\
\hline Overall & 0.147 & 0.143 & 0.121 & 0.093 & 0.066 & & & \\
\hline
\end{tabular}

Note: Grey cell means no significant correlation hence regression analysis was not conducted

Table 5 and 6 inform that Himawari 8 satellite images cannot be used to predict grass soil temperatures because vegetation cover and litter block the solar radiation, acting as a buffer of soil temperature changes (Liang et al., 2014). According to Song et al. (2013) the height and density of vegetation are inversely proportional to the soil temperature, which is associated with the increased reflection of vegetation, and decreased absorption of solar radiation by the underlying soil. Vegetation cover on the soil significantly affects the temperature and soil moisture (Özkan \& Gökbulak, 2017). Soil temperatures are more stable at the deeper parts compared to surface-surface soil temperatures (Yener et al., 2017). However, the coefficient of the determinant $\left(R^{2}\right)$ of the models are small as shown in Table 7, may due to many other climate factors also influencing the models but had not been included in the analysis. Further works on involving other 
weather elements in creating the model of the Himawari 8 satellite imagery for predicting air and soil temperatures will be necessary.

\section{CONCLUSION}

Himawari 8 satellite imagery can be used to predict the air temperature, and bare soil temperature especially at $0-5 \mathrm{~cm}$ depths. But Himawari 8 satellite imagery cannot be employed to estimate grass soil temperatures at all depths. Further works on involving other weather elements in creating the model of the Himawari 8 satellite imagery for predicting air and soil temperatures will be necessary.

\section{ACKNOWLEDGMENT}

The Authors acknowledge the
Indonesian Agency for Meteorology,
Climatology, and Geophysics, Semarang Office,
Central Java for the permission of using
climatic data for this publication.

\section{REFERENCES}

Bessho, K., Date, K., Hayashi, M., Ikeda, A., Imai, T., Inoue, H., ... Yoshida, R. (2016). An Introduction to Himawari-8/9-Japan's New-Generation Geostationary Meteorological Satellites. Journal of the Meteorological Society of Japan. Ser. II, 94(2), 151-183. https://doi.org/10.2151/jmsj.2016-009

Fan, J., McConkey, B., Wang, H., \& Janzen, H. (2016). Root distribution by depth for temperate agricultural crops. Field Crops Research, 189, 68-74. https://doi.org/10.1016/J.FCR.2016.02.013

Flores P, F., \& Lillo S, M. (2010). Simple Air Temperature Estimation Method from MODIS Satellite Images on a Regional Scale. Chilean Journal of Agricultural Research, 70(3), 436-445.
https://doi.org/10.4067/S0718-5839201 0000300011

Forsythe, N., Hardy, A. J., Fowler, H. J., Blenkinsop, S., Kilsby, C. G., Archer, D. R., ... Hashmi, M. Z. (2015). A Detailed Cloud Fraction Climatology of the Upper Indus Basin and Its Implications for Near-Surface Air Temperature. Journal of Climate, 28(9), 3537-3556. https://doi.org/10.1175/JCLI-D-14-00505.1 Geiger, R. (1959). The Climate Near The Ground. Cambridge: Havard University Press.

Jungqvist, G., Oni, S. K., Teutschbein, C., \& Futter, M. N. (2014). Effect of Climate Change on Soil Temperature in Swedish Boreal Forests. PLOS ONE, 9(4), e93957. https://doi.org/10.1371/journal.pone.00 93957

Kätterer, T., \& Andrén, O. (2009). Predicting daily soil temperature profiles in arable soils in cold temperate regions from air temperature and leaf area index. Acta Agriculturae Scandinavica, Section B Plant Soil Science, 59(1), 77-86. https://doi.org/10.1080/0906471080192 0321

Liang, L. L., Riveros-Iregui, D. A., Emanuel, R. E., \& McGlynn, B. L. (2014). A simple framework to estimate distributed soil temperature from discrete air temperature measurements in data-scarce regions. Journal of Geophysical Research: Atmospheres, 119(2), 407-417. https://doi.org/10.1002/2013JD020597

Menzel, W. P., Tobin, D. C., \& Revercomb, H. E. (2016). Infrared Remote Sensing with Meteorological Satellites. Advances In Atomic, Molecular, and Optical Physics, 65, 193-264. https://doi.org/10.1016/BS.AAMOP.2016 .04 .001 
Özkan, U., \& Gökbulak, F. (2017). Effect of vegetation change from forest to herbaceous vegetation cover on soil moisture and temperature regimes and soil water chemistry. CATENA, 149, 158-166.

https://doi.org/10.1016/J.CATENA.2016. 09.017

Patkó, I., Szeder, A., \& Patkó, C. (2013). Evaluation the Impact Tilt Angle on the Sun Collectors. Energy Procedia, 32, 222-231.

https://doi.org/10.1016/J.EGYPRO.2013. 05.029

Rahaman, K. R., \& Hassan, Q. K. (2017). Quantification of Local Warming Trend: A Remote Sensing-Based Approach. PLOS ONE, 12(1), e0169423. https://doi.org/10.1371/journal.pone.01 69423
Sadeghi, M., Babaeian, E., Tuller, M., \& Jones, S. B. (2017). The optical trapezoid model: A novel approach to remote sensing of soil moisture applied to Sentinel-2 and Landsat-8 observations. Remote Sensing of Environment, 198, 52-68. https://doi.org/10.1016/J.RSE.2017.05.041 Song, Y., Zhou, D., Zhang, H., Li, G., Jin, Y., \& Li, Q. (2013). Effects of vegetation height and density on soil temperature variations. Chinese Science Bulletin, 58(8), 907-912.

https://doi.org/10.1007/s11434-012-559 6-y

Yener, D., Ozgener, O., \& Ozgener, L. (2017). Prediction of soil temperatures for shallow geothermal applications in Turkey. Renewable and Sustainable Energy Reviews, 70, 71-77. https://doi.org/10.1016/J.RSER.2016.11. 065 